\title{
Taoist Elements in Further Biographies of Eminent Monks
}

\section{Elizabeth KENNEY}

I have searched Further Biographies of Eminent Monks 續高僧傳（T. 2050），compiled by Daoxuan 道宣 (596-667), for Taoist religious themes and images. I have looked for the names of Taoist gods and texts, references to immortals 仙 or the search for immortality 不老長生 (e.g., cinnabar 丹, mushrooms 芝, dietary practices such as abstaining from the five grains 断五穀), and even just the mention of a Taoist 道士. Only a fraction of what I have found can be presented in this short paper.

Overall, in the Further Biographies Taoism appears as a rival to Buddhism, a lesser teaching, or outright charlatanism. This is not surprising, given that the biographies cover the period of the Northern Zhou persecution of Buddhism, which (in the Buddhist telling) was instigated by the Taoist Zhang Bin 張賓, abetted by the turncoat monk Wei Yuansong 衞元嵩. We should also remember that Daoxuan was the editor of Guang hongming ji 廣弘明集 (T. 2103) and the lesser-known Ji gujin fodao lunheng 集古今佛道論衡 (T. 2104), both of which contain Buddhist polemical texts that are sharply critical of Taoism.

In one of Daoxuan's comments (論), where he is assumed to be speaking his own voice, he explicitly criticizes Taoist practices such as abstaining from grains, breathing techniques, and drugs. He writes that it is the fear of death that drives people to practice this perverse magic 邪術 (685b).

Still, Taoist skills are undeniably attractive (and the fear of death is powerful), so we find some monks who try Taoist practices before turning to Buddhism. In fact, Daoxuan's own teacher, Huizhun 慧頵 had hoped to become an immortal, studied Zhuangtze and Laotze 荘老，the Three Caverns 三洞 [Taoist scriptures], the Three Purities 三清 [abodes of the immortals], and more (533c). Similarly, a monk named Hongzhi 弘智 first practiced as a Taoist, stopped eating grains 絶粒, imbibed $q i$ 服氣, and hoped to become an immortal. In Hongzhi's case, he succeeded only in losing a 
( 20 ) Taoist Elements in Further Biographies of Eminent Monks (E. KENNEY)

lot of weight. Later a Buddhist tercher told him that food is necessary for life and,further more, the immortals are not real and the Taoist drugs are fraudulent (642a). These two biographies typify Daoxuan's presentation of Taoism as something that is understandably attractive to the ignorant and gullible. As such, Taoism can be no more than a stage in a monk's spiritual development.

In other biographies, the monks have mastered the same skills as the Taoists but spurn these arts as shallow. For example, a monk named Zhixiang 植相 stayed with a Taoist who often showed off his Taoist magic 道術. Zhixiang was completely unfrightened by the large spirit 大神 that the Taoist conjured up one night,and Zhixiang told the Taoist, "What you value is [merely] perverse magic 邪術, not the true Dharma 正法." (Note the use of the same term, "perverse magic," that Daoxuan uses in his own comment. This term appears only one other time in the Further Biographies.)

Despite Daoxuan's general rejection of Taoism, a few biographies feature Taoist immortals as heroes. Significantly, these immortals are not the monks themselves, although it could be suggested that the immortals are the true subjects of these biographies. Next I summarize two examples. The Taoist elements are italicized.

(1) Sengming 僧明 (562-642). Miracle-worker 感通. 664b-665a.

... Sengming entered a valley and saw a stone mortar and a wooden pestle 石臼木 杵. He also saw two men who were very large, cast no shadow, and had very long eye-brows. He immediatily bowed to the men. They said to him, "You stink of grain 穀臭. Where do you come from?" Sengming replied, “I practice meditation and seek the Way. Although I eat the five grains, I have vowed to become a True Person 眞人 (=an immortal)." The men said, "Please wait. We will discuss this together." All of a sudden, another man came up. He was very tall and wore clothes made of tree bark 樹皮衣. Then all four of them went further, and Sengming suddenly noticed that the valley had changed into a heavenly palace. There were fourteen or fifteen people sitting together, talking and laughing. Later, Sengming tried to return to the valley but could not find the way.

Comments: (a) I suggest that the mortar and pestle symbolize the tools of Taoist alchemy. A mortar $⿴$ is found only two other times in the Further Biographies, one of the other instances occurs in the biography summarized below. (b) There are ways to spot a Taoist immortal. The long eyebrows and the tree-bark outfit are good indica- 
tions that we are in the presence of immortals. Furthermore, the fact that they cannot stand even the scent of grain is a give-away. (c) Immortals can appear and disappear in an instant. (d) Immortals prefer to live in far-away, mysterious places.

(2) Sengzhao 僧照. Miracle-worker 感通. 647a-b.

...In the year 531, Sengzhao entered a tunnel under a waterfall, walked a while, and then came out. After walking some more, he saw three small huts. Grain grew untended all around the huts, and birds were eating the grain. In the first hut, there were shelves of books with yellow covers. In the middle hut, there were two iron mortars and a cauldron all covered with dust. There was no evidence of cooking. In the third hut, there was a monk 沙門, sitting upright with his lap filled with dust. There were no other people around. Suddenly, from out of nowhere, a divine monk 神僧 appeared.He was about sixty years old. His eyebrows were more than three meters long (丈餘) and curled around his ears. He said to Sengzhao, "My fellow practitioners came here to escape the world. One of them [in the middle hut] went out and hasn't come back. The other one [in the third hut] died a long time ago. It seems that he has entered nirvana 入滅定. Didn't you see him just now [in the third hut] ? By the way,] what is the name of the dynasty now?" Sengzhao answered, "Wei 魏." But it becomes clear that the monk mistakenly thinks Sengzhao means the earlier Wei Dynasty (220-265), not the current Northern Wei (386-534). So this Chinese Rip Van Winkle has lost track of at least 266 years (remember, this story is explicitly dated to 531), and he must be about three hundred years old himself (though he looks only sixty). The monk gathers grains and makes gruel. He goes to the forest to collect pears and jujubes 梨霜. He gives this food to Sengzhao but does not eat anything himself. The next day, after the monk has chanted sutras all night, Sengzhao leaves. Later, just like Sengming, he is unable to find his way back to this special place.

Comments: The old man is always called a "monk" 僧, and Buddhist terms and practices are mentioned. But almost everything we learn about this monk marks him as a Taoist immortal: he is hundreds of years old; he has incredibly long eyebrows; he does not cultivate grain; he doesn't eat ordinary food; he doesn't sleep; his two friends seem to have achieved immortality, one perhaps through elixirs (remember the mortars and cauldron), the other through a physical deathlessness.

As mentioned above, Sengming and Sengzhao are not themselves Taoist immor- 
tals. The two monks are merely witnesses, who--to their regret, it seems--cannot find their way back to get a second glimpse of immortality. The immortals are the real stars in these two biographies, with the monks reduced to walk-on roles in their own lives.

There are some biographies in which the monk (or nun, as we shall see) actually does follow Taoist practices and does not reject such practices or outgrow them.

(3) Two unnamed nuns who were sisters. Body-sacrificers 遺身. 683c-684a.

$\cdots$ In the year 630 , two nuns set fire to themselves with a large and pious group of onlookers. In preparation for their immolation, the nuns drank fragrant oils and gradually gave up eating rice. At the end, they suddenly stopped eating grains altogether and ate only honey.

Comments: As other scholars have noted, the various Chinese Buddhist biographical collections state that a few of the monks and nuns who commit suicide (often, but not exclusively, through self-immolation) stop eating grains before killing themselves. In the case of the two nuns above, their choice of honey as their sole food reflects a Taoist influence. From the Buddhist perspective, honey might seem an indulgent choice, too sweet and high calorie. However, from the Taoist point of view, honey makes sense because it is natural and uncultivated by humans.

\section{Conclusion}

An examination of Taoist elements in Further Biographies of Eminent Monks reveals a spectrum of roles for Taoism in the lives of Buddhist monks. For the most part, Daoxuan is hostile to Taoism. In some cases, Daoxuan extends a grudging tolerance toward Taoist skills. In a very few cases, Taoism receives a sympathetic portrayal, as in the biographies of Sengming and Sengzhao. We might wonder why Daoxuan included this material, which serves only to make Taoism attractive. Here it is well to remember that Daoxuan collected miracle stories and was clearly powerfully attracted to the supernatural (the evidence is all through the Further Biographies).Daoxuan himself surely realized that some of the biographies present the immortals and Taoism in a very favorable light--but I guess some stories are just too good to resist.

〈Key Words〉 道宣, 續高僧傳, 道教

(関西外国語大学助教授) 